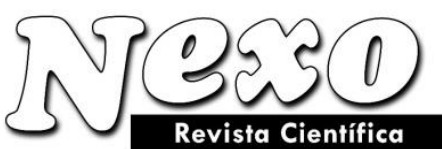

Vol. 34, No. 01, pp. 258-269/Marzo 2021

\title{
Crypto currency's "economic nature" in the light of new monetary theory
}

\section{"Naturaleza económica" de la moneda cripto a luz de una nueva teoría monetaria}

\author{
Vyacheslav I. Karpunin ${ }^{1,2^{*}}$, Tatiana S. Novashina ${ }^{2}$ \\ ${ }^{1}$ Moscow State Institute of International Relations (University) of the Ministry of Foreign Affairs of \\ Russia, Russia. \\ ${ }^{2}$ Synergy Moscow University of Industry and Finance, Russia. \\ *vikarpunin@mail.ru
}

(recibido/received: 19-November-2020; aceptado/accepted: 18-January-2021)

\begin{abstract}
The systemic and functional analysis of economic nature of Crypto currency within the modern theory of money is a necessary essential component of the study that allowed the authors to formulate a vision of social and economic model of future international monetary system. The authors consider the substance of money in a dialectic unity of the transformation of forms and spheres of its being. The forms of being of money are: material, monetary, paper, electronic. The spheres of being of money are: social, - the "symbol money"; economic, - the "bank notes"; political and legal, - "monetary units". In this paper we show that money is a financial instrument. Money is a market form of universal claim to a share in the wealth of society. The uncovering of internal intrinsic structure of money allows the authors to show convincingly that a currency, especially a "Crypto currency", cannot have and does not have an "economic nature". In considering the process of historical transformation of international monetary systems, taking into account the real achievements of financial, information, program and social engineering for the creation of a digital "gold" the authors believe that the social and economic model of future international monetary system has received its real approbation.
\end{abstract}

Keywords: Currency; Foreign exchange market; Monetary unit; Bank notes; Electronic money.

\section{RESUMEN}

El análisis sistémico y funcional de la naturaleza económica de la criptodivisa dentro de la teoría moderna del dinero es un componente esencial necesario del estudio que permitió a los autores formular una visión del modelo social y económico del futuro sistema monetario internacional. Los autores consideran la sustancia del dinero en una unidad dialéctica de la transformación de formas y esferas de su ser. Las formas de ser del dinero son: material, monetario, papel, electrónico. Las esferas del ser del dinero son: social, - el "símbolo del dinero"; económico, - los "billetes de banco"; político y legal, - "unidades monetarias". En este artículo mostramos que el dinero es un instrumento financiero. El dinero es una forma de mercado de reivindicación universal de una participación en la riqueza de la sociedad. El descubrimiento de la estructura intrínseca interna del dinero permite a los autores demostrar de manera convincente que una moneda, especialmente una "moneda criptográfica", no puede tener y no tiene una "naturaleza económica". Al considerar el proceso de transformación histórica de los sistemas monetarios internacionales, teniendo en cuenta los logros reales de la ingeniería financiera, de información, de 
programas y social para la creación de un "oro" digital, los autores creen que el modelo social y económico del futuro sistema monetario internacional ha recibido su aprobación real.

Palabras clave: Moneda; Mercado de divisas; Unidad monetaria; Billetes de banco; Dinero electrónico.

\section{INTRODUCTION}

The "economic nature" of such a phenomenon of modern financial market as "Crypto currency" is the starting logical point of the study.

On the basis of a critical analysis of theoretical propositions stated by A.Yu. Simanovsky, a board member of the Bank of Russia (2007-2017) in a scientific and journalistic article Regarding the Question of Economic Nature of Cryptocurrency (Simanovskiy, 2018), the authors of the article are floating a synthetic judgment that a currency including the so-called "Crypto currency", does not have, and cannot have in itself an economic nature.

This judgment is not rhetorical and does not belong to the realm of scientific casuistry. This question is an essential one, principled, and if we consider not the single phenomena, for example, the phenomenon firing the imagination of naive investors the "record" of market capitalization of "Bitcoin" on January 8, 2021 of 41,845 USD (Bitcoin rate..., n.d.), but the depth of relationships arising in this regard, this judgment touches on the most important issues of ensuring the stability of a national financial system, ensuring the sovereignty of any national jurisdiction.

Synthetic judgment is an important logical tool introduced to the realm of abstract scientific thinking by German philosopher I. Kant (Immanuel Kant, 1724-1804). I. Kant believed that there could be both $a$ priori, and a posteriori synthetic judgments, the judgments "expanding knowledge", introducing something new about the object of study (Kant, 2018).

The statement of a problem of understanding the economic nature of money (economic nature of "currency" from the point of view of certain reputed scholars (Simanovskiy, 2018)) formulated by whoever or whenever, does in itself attract great scientific interest not so much with young scholars who are just starting to comprehend the truth of the economic being of money, as with adherents of various economic schools. See for example, Yu. Bazulin (2008; 2009; Sokolov, 2009, p. 432), H.D. Chang (2015, p. 18), M. Portnoy (2017), or even F. Mishkin (2015, p. 83-97).

The notions of "money" and "currency" should not be confused and more so, equated. As these concepts reflect substances of different order. Historically we are talking about the weight content of a monetary unit - coins in the period of "absolute reign" of coin form of money (be it gold, silver, platinum or copper). For example, the Kingdom of Sweden (1620 - 1766) used a bimetallic monetary system - there were in circulation at the same time as a legal tender the coins minted from silver and copper. And during 1599-1632 the coins were minted from gold as well. Sweden used a polymetallic monetary system. We do not ask a question why? For that there were significant economic reasons. In the context of this narration we are only stating the fact.

Today in the legal framework of the Russian Federation and, as a result, in legal and economic practice the notion of "currency" is used as a synonym of "bank notes" - a "legal tender" and/or "cash on bank accounts and in bank deposits" (Federal law N 173-FZ, 2003).

In the university academic textbook, F. Mishkin, an adherent of monetarism theory, sets forth the financial market structure (today it is a ubiquitous point of view both in academic literature, and among professional financial market participants). In short, several segments of financial market are 
distinguished, in particular, a "money market" segment and a "foreign exchange market" segment. Firstly, it is different economic purpose of these markets (functions assigned by economic agents over the transactions made by them), secondly, "currency" and "money" are substances of different order (Mishkin, 2015, p. 41, 53, 64, 78). At the same time, it is specially emphasized that the "foreign exchange market has, owing to exchange rate fluctuations, an essential value for economy" (Mishkin, 2015, p. 53). The "money market is a financial market in which trade in short-term debt instruments only is carried out" (Mishkin, 2015, p. 64). Including, apart of money, in securities.

In the "money market", unlike the "foreign exchange market", the financial instruments are traded that are essentially different in economic and legal substance.

The main criterion of classification (segmentations) of money market is the degree of liquidity of financial instruments. On the contrary, money per se is what is traded in the market of loan capital. In this case, both buyers and sellers of money (money is a financial instrument endowed, unlike all other financial instruments, with special, specific functions), by concluding "purchase and sale" transactions in economic respect, enter in legal respect into the legal form of "loan", i.e. they enter into credit relations, making a loan transaction. In all transactions of loan (credit) nature, despite the Art. 823 of the Civil Code of the Russian Federation specifically defining a "commercial credit" as the "transfer into the ownership to other party of sums of money or other things" (Civil Code of the Russian Federation No 14-FZ, 1996), a fundamental principle of the credit - recoverability is in force. Money (cash) is transferred by the creditor into the possession to the borrower. The legal property relation implies a triad - possession, disposal, use. There shall be transferred into ownership the "sums of money or other things". The property title to "money", with all the rights following from this legal relationship, belongs to the borrower. The borrower disposes of money at his own discretion (except for the instances of restriction provided for by a loan agreement to minimize a credit risk). But, at the same time, there shall accrue an obligation of the borrower, owing to specific features of the credit relations, to unconditionally repay the money (sums of money) received into ownership.

Let us emphasize. In credit transactions "money" acts as such (along with other things (property). The money (along with other things (property) is to be repaid unconditionally. No "credit money" exist as such. In credit transactions there exist legal relationships of credit that prescribe to the borrower the unconditional return of the loaned property - "money", "property", including grain, dates, or precious metals - "silver". Or, today, "gold".

Whereas the foreign exchange market is intended for other financial transactions. Exclusively for "conversion, - an instrument of movement of financial means between countries". And further "An exchange rate is the price of a unit of currency of one country expressed in monetary units of another country" (Mishkin, 2015, p. 41). The fact that in this market there is a powerful and extremely productive speculative factor behind actual "pricing" at exchange rates, is a historically evident one. G. Soros has publicly revealed "secrets" of speculative mastery, stating the "theory" of speculative play (Soros, 1996, pp. 34-97), long before December 2014, when the management of the Bank of Russia admitted its own helplessness, allowing to occur a devaluation of national currency having no precedent by scale. And as an answer to the management of the Bank of Russia to its reckless actions regarding manipulations with "key interest rate": "notions of importance of interest rates are often wrong" (Soros, 1996, p. 88).

\section{STATEMENT OF THE PROBLEM}

The one to delve deepest and most thoroughly than all into the economic nature of money was, in our point of view, Yu. Bazulin. The author of a new scientific theory revealing the "nature of money" defines the substance of "money", and we specifically stress it, through a Hegelian triad - "money is a market form of universal claim to a share in the wealth of society" (Bazulin, 2008, p. 432). 
"The reason of war and conflict situation are violations in the structure social the relations and absence of settled social and economic cultural traditions, their basic element - a universally recognized form of money" (Bazulin, 2008, pp. 190-219).

The stability of a national monetary unit, purchasing power of money is determined (according to Bazulin) in the first place by the social status of national elite, its social and political power.

We find the understanding of this substance of money in other authors, too. The authors which cannot be united neither by language of thinking, nor by mentality or socio-political culture, but they should be recognized as like-minded persons in the understanding of the essence of this extremely important civilization phenomenon as "money" - "money is a symbol of your claims to certain volumes of resources of society" (Chang, 2015, p. 18).

The key element used in the definition of a logical triad is the legal relationship in economic circulation (market form) of a financial instrument - "money". This legal relationship is the "universal claim". This key provision is a cardinal difference from the definition of substance of money, which follows, for example, from the opinions of followers of monetarism "a highly liquid financial asset". "Money is a peculiar asset of society. It is not just an asset, rather, it is a highly liquid asset, the liquidity of money as an asset being higher than the liquidity of all other assets (even such financial assets as shares, corporate bonds, etc) (Moiseyev, 2018; Lavrushin, 2010). Especially impressive in this list of "financial assets" is their infinite subject diversity (Lavrushin, 2010, p. 23, Lavrushin, 2014, p. 29). And this judgment is set forth as an "indisputable and paramount truth" in an infinite series of stereotyped reprints of a textbook intended for "baccalaureate, postgraduate students and instructors of economics faculties and higher education institutions, scholars, and workers of financial and banking systems" (Lavrushin, 2010, p. 2; Lavrushin, 2014, p. 2). From our point of view the statements of this sort ("highly liquid asset") are not just a theoretical nonsense, but a harmful political and economic ideologism! It is based on theoretical postulates of this sort and their consequences - purposeful ideologisms that modern monetary policy of Russia is born and, what is most important, prospers.

\section{WORKING HYPOTHESIS AND METHODOLOGY}

Perhaps each of us, especially the one who reads this article, having encountered the phenomenon of "Crypto currency" either directly, or indirectly - by hearsay, had the question what kind of a phenomenon it is. There are many judgments pretending to characterise the substance, and especially the advantages of "Bitcoin", and other "altcoins" along with it. One of these judgments is this - "Crypto currency" is a digital financial asset, property in electronic form. Any "asset" is a property, from the point of view of law, from the point of view of financial accounting. But an asset, including a financial one, has quite a specific form. There are many forms of existence of financial assets. For example, any specific set of securities can be classified as financial assets if these securities are owned by one or another economic subject. In addition, "financial assets" (according to financial accounting) include "cash" (cash in hand, settlement accounts in banks), "securities" in electronic (digital) form (custody accounts in banks). Therefore, the statement "a financial asset is a property in electronic form" is a statement banal by its substantive essence, one that does not introduce a constructive element into the conceptual framework of the draft federal law.

Let us imagine our vision of the notion of "Crypto currency" based on the factual position which is today held by this phenomenon in economic space. "Crypto currency" is a financial instrument existing in the system of consensus register (ledger) in electronic form as a digital code.

The consensus register (ledger) allows to carry out transactions between accounts without commission, without involving a third party as a guarantor of completion. 
Any financial instrument is created (financial engineering) for the performance of a certain set of functions projected in advance. From the point of view of fundamental requirements to a projected "financial instrument" the financial engineer must consider (in the process of management and future financial circulation of a "financial instrument") five key components: 1. Liquidity. 2. Temporary structure. 3. Sensitivity to interest rates. 4. Structure of validity periods. 5. Credit risk. (Marshal, Bansal, 1998; Sokolnikov, 1995). This is "classical approach" in the framework of "classical" financial engineering.

"Crypto currency" is a financial instrument designed and launched into economic (financial) circulation with a view of achieving certain purposes. What are these purposes?

Main (strategic) purpose:

- Giving to a specific type of "Crypto currency" the status of the main universal payment unit, the replacement of dollar in this function as an international means of payment in the economy of future.

Intermediate purposes:

- Fixing in mass consciousness of the concept of "Crypto Currency" as an economic reality, as a unique means of payment having advantages, but deprived of shortcomings of classical ones that now exist.

- Receiving a current (in real time), speculative (a powerful driver), operational (fixing for "Crypto currency" of the status of a "financial instrument" as such) benefit.

In the designing of financial instruments, the principles and procedures generally used are those of financial engineering.

In the designing of a "Crypto currency" and primarily in the designing of its first public form - the "Bitcoin", there have been used the achievements (scientific developments and a rich accumulated international experience) in the sphere of financial engineering, in the sphere of information engineering, in the sphere of program engineering.

In the launching into economic circulation, in efficient functioning and market expansion of a "Crypto currency" and primarily of its first public exterritorial form - the "Bitcoin", broad and active use is made of the rich arsenal of means of social engineering.

\section{RESULTS}

\subsection{Historical note}

The notions in science arise as an intellectual reaction of a researcher to the realities of being, for the purpose of describing a phenomenon, and to get to know the essence and its nature.

In various subject domains of scientific knowledge there can be used the same terms, sometimes borrowed by researchers from the sphere of spoken language, or created specially, artificially, or designed, or fancied, or composed on the basis, "dead" languages - Latin, Ancient Greek. There are many variants, and the choice is big.

In doing so, the task of a researcher is not to formally fix in public conscience a new term by means of phonetics, how it sounds, rather, to use visual images also by means of inscription with characters (signs). The task is to comprehend the essence of the phenomenon that the term is designed to designate. At first 
in theory. Then, perhaps not at once, indirectly, in the practical activities of humans directed at achieving some goals.

The emergence of new notions in economic science is not an exception. Thus, for example, the notion of "inflation" arose in the last decades of $19^{\text {th }}$ century. Though this phenomenon as we understand it today has existed long before the beginning of new chronology. A new term appeared to designate a phenomenon identified by an inquisitive mind. But that was not enough. One needs to describe the essence of the phenomenon, i.e. one needs to fill this new term with economic contents, to pass from single (phenomenon) to general (essence). One needs to formulate the essence of the new term as an economic category.

"Inflation" as a macroeconomic phenomenon, the management of this phenomenon fell within the scope of interests of government economic (monetary) policy. Today "inflation" is a special subject of management (inflation targeting) of most Central (National) banks.

Emergence of notions in economic science, "presence" of many phenomena in the sphere of political and economic interests of a state is a universal phenomenon today.

The widely used notions (external form) in one or another scientific and practical spheres can flow to other subject domains of knowledge and activity.

In the last decades of $20^{\text {th }}$ century, the traditionally basic notion of "inflation" in economic sphere entered scientific circulation in cosmology (1981) as model of cosmic inflation, the inflationary expansion of the Universe. 33 years later (2014) indirect demonstrations of a number of provisions of inflationary model were obtained. However later these data were not confirmed. As of today, the inflationary model of expansion of the Universe remains only an attractive hypothesis.

We also have a peculiar historical transformation of an economic notion with such economic, financial term as "currency".

Virtually all modern academic textbooks on the international monetary relations, international finance feature a periodization of international monetary unions and systems based on them, which become a traditional view owing to this fact. The periodization begins from a signature time, a historical phenomenon - the ends of Napoleonic wars.

Let us present this periodization as briefly as possible.

Great Britain. Gold standard. 1821

France. International agreement. 1865

\section{Latin monetary union}

\section{Modern name Paris currency system}

Great Britain. France. International conference. 1922

\section{Genoese currency system}

USA. Great Britain. Bretton Woods international conference (Bretton Woods system). 1944 


\title{
Bretton Woods currency system
}

\author{
USA. International Monetary Fund. 1976 - 1978
}

\section{Jamaican currency system}

The analysis of purposes, principles, substance of arrangements of the international agreements listed that touch on the sphere of geopolitical, geo-economic interests of the parties, allows to assert that as a result of historical processes of repartition of spheres of influence, fight for territories, resources, markets, as a result of wars and subsequent cataclysms, the transformation occurs of both the forms (unions) and the contents of international financial arrangements. At different times (different unions) the strongest party which proved itself in these historical conditions acts as dominant force of the changes (other arrangements). This force (these forces) implements its own vision of the forthcoming transformation, setting and implementing the objectives based on its own interests, based on its capabilities.

The dialectics of these transformations is such that monetary interest is regarded as of paramount importance - money as an unconditional "universal claim" to a share in the wealth of society, causing the dictate and pressure in the process of expansion of global "creditors - debtors" contradiction (Novashina, Karpunin, 2020). Implementing the dictate and pressure primarily by means of financial (economic) mechanisms.

There has occurred a historical transition, transformation of the "universal claim", a legal component of money, from a full-fledged gold coin (requirement of "stability" is an especially high-quality minting of a coin), to a fiat paper (from lat. Fiat - decree, order, "let it be done") US Dollar (requirement of "stability" is a ubiquitous credit expansion).

\subsection{From real gold coins to virtual gold coins}

As a result of the transformation of gold standard as a monetary system the "coin" money form has finally and everywhere has given way to the "paper" money form.

These two dominants form of money have for a long time coexisted together at different times and in different conditions. The Genoese currency system has forever changed this relationship. The Jamaican currency system has implemented the task set when it was designed and launched - strengthened the international position of US Dollar, has finally turned the paper (fiduciary) (from lat. Fiducia - trust) form of money into the leading component of national monetary systems. There had been defined the existence of currency parity as an uncontested condition of international payments theoretically set on the basis of SDR, while in practice each country began to define independently the mechanism of formation of the parity of national currency and the regime of its circulation.

The notion of "currency" has firmly and permanently entered the business circulation of international financial relations. Considering this extremely important circumstance, some theoretical explanations have to be made. Just like the Latin monetary union has at the time defined the weight ratio of national monetary units, gold coins, in new conditions (the US monetary authority effectively dictated its will to the IMF) the Jamaican currency system has put the national monetary units, now designated by the term "currency", in a free market regime of exchange rate setting mechanism with a peg to the US Dollar. As a result, strongly held views have formed of the notion of "currency" in the sphere of financial relations, this is both theory (science) and practice (market), this is financial law and statutes of government regulators. From now on the notion of "currency" is directly associated with the notion of "monetary unit". This circumstance is recorded also in a number of reference media, academic textbooks. But it is not surprising as their compilers and authors generally use the information borrowed from practical business conduct. 
Thus, practice predetermines the "contents" of theoretical (realm of abstract thinking) notions, and not vice versa. From single to general. Well, such is a winding path to the truth. But the notion of "monetary unit" is not equivalent to the notion of "money". Moreover, a monetary unit is just a legal form of the being of money as such. Money as a social and economic category has three intrinsic forms of being. "Symbol money" is the social form of the being of money. "Bank notes" is the economic form of the being of money. "Monetary units" is the legal form of the being of money (Bazulin, 2008).

As of today, as a result of development and mass use of electronic computing systems and electronic channels of communication, the next in order monetary form (after material, monetary, paper form) is becoming widespread. It should be especially noted that the notions of "credit transfer" (non-cash) and "electronic" money do not coincide.

Firstly. Criteria of classification. Criteria are different, varying, not the same.

Secondly. Time. The time of emergence in economic circulation is different. Non-cash money, in the form of entries in account books, existed in social and economic circulation long before the emergence of electronic equipment and, therefore, long before their electronic form.

Thirdly. Technology. And what is the most important, the technological manner of emission and economic circulation of electronic money is peculiar. It is the technological features of emission and circulation, type of material, technological and economic availability of this material that predetermine one or another monetary form. The next in order monetary form with which humans are likely to come into contact, is inexplicit. It is quite possible that it will be a quantum money form. For this purpose, all prerequisites have been created today. Both technological and political, financial, and economic.

Further development of electronic communication, information, functional systems approaches the limit of power support of its functioning on the basis of available electricity generation capacities. There will come for the mankind the natural limit of further increase in quantity and growth of power of electronic systems. Including the systems that serve the emission and flows of electronic money. Any alternative? Quantum technologies. In the sphere of finance, quantum money. It is the second virtual money form, along with electronic form, and perhaps the last one from those implemented today.

\section{DISCUSSION}

In this regard let us turn our attention to the most significant and high-profile "Project" of modern era in the field of finance - the project under the conventional name of "Bitcoin".

We have already talked (Karpunin, 2018) about the intrigue of origin and goal-setting, mechanism of expansion, driving interests, intrinsic principles of the Bitcoin Project. Let us cite the propositions that are most significant for our research.

\section{Firstly. The materialization of idea}

"Bitcoin" ("Bitcoin") is the proper name of the first variant of so-called "virtual currency" that the "author", and many others after him, have preferred to designate as "electronic cash". As it appears to us, the idea of such a meaningful interpretation of "Bitcoin" had to emphasize by design of the "author" the functional proximity of a "virtual electronic financial instrument" to the cash paper money in their function of legal tender. Primarily, in one very characteristic feature of paper money - the ease of changing hands (such ease allows to ensure anonymity of transaction, if necessary). And to fix thereby in the conscience of a user ("coin", "cash") that Bitcoin potentially belongs to money. 


\section{Secondly. The birth of the term}

The American financial and economic magazine Forbes posted an op-ed article under the name "Crypto currency" by Andy Greenberg, a journalist, editor of Forbes USA, about the Bitcoin system, after more than two years from the date of public presentation of "Bitcoin" with a functional description as "electronic cash". It is this day that became an informal date of birth of the term "Crypto Currency". In this was the "Bitcoin" was given the status of "Currency" (there are grounds to believe, not incidentally at all). Predetermining thereby a potential possibility of using an electronic and digital financial instrument in the functional role of money - the means of payment.

The basic provisions of systemic stability of the Bitcoin Project and other system features of the Project are covered in the publication (Karpunin, 2018). The total number of identified unique systemic features of the Bitcoin Project is ten.

\section{Thirdly. "Digital gold".}

Let us specially emphasize the "digital gold" Project.

Book by the journalist, economic observer of the New York Times newspaper Nathaniel Popper Digital Gold: Bitcoin and the Inside Story of the Misfits and Millionaires Trying to Reinvent Money topped the charts of business books in the Financial Times rating (2015) (Popper, 2016).

In this regard we draw attention to a single, but extremely important circumstance - the notion of "digital gold" is being introduced into public consciousness. "Digital gold" is also appearing in Russian-speaking public space, in the form of epistolary genre, in the form of a perfectly published e-book (Filippov, 2017). Its author started his career in the foreign Forex exchange market. Wrote more than 800 articles as an analyst. Publishers made a right choice. Such an author will be listened to. And on 38 pages of the book the publishers placed seven (!) colourful pictures of a "gold bitcoin" in an image of a gold coin, and in one of pictures even "sitting solemnly" on a gold ingot, weighing probably as a standard 400-ounce $(12,441.39072$ grams) Ingot! A commendable example.

The image of "Bitcoin", but now not as a symbol, rather as a real gold item - electronic wallet is available for sale. From a "virtual" gold coin to a real gold. In this, the creators of the project have a deeply pragmatic meaning that exploits stereotypes that have been rooted in human consciousness for millennia. Money as a social and economic category has three intrinsic forms of being. "Symbol money" is the social form of the being of money. "Bank notes" is the economic form of the being of money. "Monetary units" is the legal form of the being of money. Before becoming money, the money must be initially accepted by the consciousness of an individual as such. So "symbol money" appear. It is one of the forms of solution of the main objective - the transformation, a very unusual one, of a financial instrument into a "universal claim to a share in the wealth of society".

Another such form, with a similar task, is the act of "market" exchange (sale) of pizza (goods) for "Bitcoin" (money), which was calculated in advance, planned and skilfully executed. Let us build a logical sequence. Firstly, the visible one (actual fact), then calculated one (desirable contents): exchange of pizza for "Bitcoin"; a sale of goods for money. We assert, moreover, we are sure - the timepoint of making this "exchange" was not an incidental phenomenon. The timepoint was chosen in advance, accurately calculated, and implemented according to calculated time. In this way a major act was implemented, for the sake of which the "Bitcoin" was created in the first place - a conscious, pre-planned demonstration of one of money functions, the function as a "means of payment". 
The "Bitcoin", and to be exact, the "fantastic success" of capitalization of this virtual currency, elevated by prudent marketing specialists, who were exploiting human weakness of greed for profit, to the heights unprecedented hitherto even for the most known in the history of financial pyramids, infatuated many who as early as yesterday were not even thinking to tie with it their today and tomorrow.

Infatuated entrepreneurs and average people, the public, corporate servants and students, forcing to engage en masse in the "extraction" (mining) and trading of virtual currency.

Infatuated university faculty, encouraging to take on the status of "experts" having just touched the "depths of theory" of this phenomenon.

Infatuated political figures, members of governments of various description and level, monetary management authorities, encouraging not only desire to attend public lectures, hear specially prepared reports on virtual currencies and their regulation, but also to make fateful decisions related to its future.

The "economic nature" of a currency, including the "Crypto currency", does not exist per se, does not exist in essence. As we have showed, currency is a notion related to the legal status of money, but not in any way with economic one. Engaging in scholasticism is not rewarding. But in our reasonings there is quite a certain common sense.

There is a judgment. That judgment is not stated by us. That judgment is rather disputable, and nevertheless we will cite it. The only way for the USA to avoid hyperinflation is to introduce gold standard. But the problem is where to take so much gold from. The USA does not have the amount of gold required for such a systemic revolution in the world of finance.

Because of physical shortage of necessary amount of gold, the USA abandoned the gold standard (1971, $37^{\text {th }}$ U.S. President - Richard Milhous Nixon) for the ever increasing emission of USD. An emission associated with the global credit expansion of USD (Novashina, 2019; Novashina, Karpunin, 2020).

Back in the day in the USA, undoubtedly with the consent of the monetary authorities, there had been undertaken and implemented the project of mass falsification of bank ingots of gold weighing standard 400 ounces. These were the so-called "tungsten ingots". Tungsten ingots were released, by some estimates, in quantities of several one million pieces, a part of which was really coated with gold, had registration numbers belonging to the USA, and were stored in Fort Knox. The falsification was publicly revealed. The information on tungsten gold was confirmed by GATA (Gold Anti-Trust Action Committee). This fact was not disproved by official authorities ( $42^{\text {nd }}$ U.S. President - William Jefferson "Bill" Clinton). The project of "tungsten gold" failed. But a new project appears - the "digital gold" project.

We again focus our attention on a very important phenomenon: back in the day a historical transition occurred, a systemic transformation of "universal claim", a legal component of money, from a fullfledged gold coin (requirement of "stability" is an especially high-quality minting of a coin), to a fiat paper US Dollar (requirement of "stability" is a ubiquitous credit expansion) (Novashina, 2019; Novashina, Karpunin, 2020).

Today we are observing a new phenomenon, a new historical transition, a new systemic transformation. It is the so-called "virtual project for virtual economy" (Karpunin, 2018). The task was set to make, contrary to the laws of formal logic, the reverse systemic transition from a fiat digital instrument - "Bitcoin", to a full-fledged gold "coin". But in new historical conditions this coin must be virtual. 
If this transition succeeds, it will mean that the deepest component of the being of money - symbol money will acquire in conscience of individuals the social status of a full-fledged money. This process provides as a necessary logical and social and economic component for the carrying out of an experiment today, and thereafter for a wide use of Central Bank Digital Currency. In the prospect perceivable by humans central banks of the world will transit to the universal use of Digital Currency. The fiat paper US dollar will give way to a virtual gold coin. It does not necessarily have to be the "Bitcoin".

The unique and very expensive project, with clearly calculated internal political and economic logic of expansion has already paved the way to the digital gold. And it is a historic fact.

\section{CONCLUSION}

Scientific and technical progress is inevitable and obvious.

Inevitable - by the human nature itself.

Obvious - to the generation today owing to the existence of the very fact of high dynamism of technological transformations.

Social and moral progress in today's dramatic period of existence of mankind is not unambiguous and is problematic.

Not unambiguous - social systems are functioning with high uncertainty and multi-variance of possible results.

Problematic - the "mankind as whole has lost the meaning of its social being itself" (Zinovyev, 1999).

It is the ability to create, keep, accumulate social and cultural traditions of society, including money, to "pass on" these values to other communities that in the conditions of globalization, in the conditions of geopolitical and geo-economic cataclysms of modern World is the mission of national elites.

\section{ACKNOWLEDGMENT}

The authors pay tribute to the memory of Yu.V. Bazulin, professor of Saint Petersburg University, a profound and original thinker, an infinitely modest person, who managed on to take a new look at the phenomenon "money" and to help us to move significantly deeper and further for better understanding of the essence and future of virtual currencies projected by human.

\section{REFERENCES}

Bazulin, Yu. V. (2008). Origin and nature of money. St. Petersburg: Publishing house of Saint Petersburg University.

Bazulin, Yu.V. (2009). Origin and nature of money: financial aspect: abstract of thesis. St. Petersburg.

Bitcoin rate, Bitcoin online chart, BTC / USD quotes. (n.d.). TorFOREX.com. Retrieved from: https://torforex.com/bitcoin-chart/

Chang, H.J.C. (2015). Economics: The User's Guide. Moscow: Mann, Ivanov and Ferber. 
Civil Code of the Russian Federation No 14-FZ. (Jsnusry 26, 1996). Retrieved from: https://rg.ru/2008/05/22/gk-2-dok.html

Federal law No 173-FZ. (December 10, 2003). "On currency regulation and currency control". Retrieved from: https://rg.ru/2003/12/17/valuta-dok.html

Filippov, E. (2017). Cryptocurrency from "A" to "Z". Moscow: STFOREX.

Kant, I. (2018). Criticism of Pure Reason. Moscow: Eksmo.

Karpunin, V.I. (2018). A virtual project for virtual economy: about "Crypto currency" and not only. Bulletin of Plekhanov Russian Academy of Economics, 3(99), 33-49.

Lavrushin, O.I. (2010). Money. Credit. Banks. Express course: teaching aid. Moscow: KNORUS.

Lavrushin, O.I. (2014). Money. Credit. Banks: textbook. Moscow: KNORUS.

Marshal, J.F., Bansal, V.K. (1998). Financial Engineering: A Complete Guide to Financial Innovation. Moscow: INFRA-M.

Mishkin, F.S. (2015). The Economics of Money, Banking, and Financial Markets. London: Pearson Education.

Moiseyev, S.R. (2018). Renaissance of monetarism: what the prominent theory subsisted on in 2000-2018. Voprosy Ekonomiki Publishers, 1, 24-42.

Novashina, T.S. (2019). Modern monetary policy of Russia in the light of the theory of dysfunction of money. Bulletin of Plekhanov Russian Academy of Economics, 1, 19-26.

Novashina, T.S., Karpunin, V.I. (2020). Genesis of global systemic contradiction of modern time. Revista Inclusiones, 7(Especial), 96-115.

Popper, N. (2016). Digital Gold: Bitcoin and the Inside Story of the Misfits and Millionaires Trying to Reinvent Money. Moscow: Williams.

Portnoy, M.A. (2017). Money in national and world economy. Moscow: Magistr Publishers.

Simanovsky, A.Yu. (2018). Regarding the Question of Economic Nature of Cryptocurrency. Voprosy Ekonomiki Publishers, 9, 132-142.

Sokolnikov, G.Ya. (1995). New financial policy: on the road to a hard currency. Moscow: Nauka.

Sokolov, B.I. (2009). Review of the book by Bazulin, Yu.V. Origin and nature of money. Voprosy Sovremennoy Ekonomiki Publishers, 4, 431-432.

Soros, G. (1996). Alchemy of Finance. Moscow: INFRA-M.

Zinovyev, A.A. (1999). The West against Russia. View of a philosopher. Interview of A. Zinovyev with V. Lupan for Le Figaro edition. Berlin. 